\title{
ASSESSMENT OF THE OUTREACH PERFORMANCE OF SPECIAL PROGRAMME ON FOOD SECURITY IN ABIA STATE, NIGERIA
}

\author{
R.O Mejeha and S.E. Ogbe \\ Department of Agricultural Economics \\ Michael Okpara University of Agriculture Umudike, \\ P.M.B 7267 Umuahia, Abia State
}

\begin{abstract}
This study assessed the performance of Special Programme on Food Security with respect to outreach of microcredit service. The study covered the first phase of the programme in Abia State, the study area. One hundred and twenty participants of the programme were purposively selected from the three programme sites of SPFS. The respondents were made up of 60 micro-credit beneficiaries and 60 non-beneficiaries. Two sets of structured questionnaire were used for data collection. The data collected were analysed with simple statistical tools such as percentages, frequency distribution and means. Multiple regression analysis and outreach indicators were used in data analysis. The results indicate that SPFS operators used laid down criteria in selecting loan beneficiaries. Four variables namely level of education, skill acquisition in off farm activities, farm size, and loan transaction costs produced significant influence on the amount of loan demanded. $R^{2}$ value of 0.529 indicates that the explanatory variables in the model explain 52.9\% of the total variation in the amount of loan demanded. The outreach level of the programme in the State in the first phase was $0.052 \%$ of the target population. Similarly, women loan beneficiaries constituted $30 \%$ of the total number of beneficiaries in the programme. The number of loan beneficiaries across the State is evenly spread indicating fairness in the allocation of financial resource. Constraints encountered by the programme are limited amount of funding and some administrative bottlenecks. It is therefore recommended that more funds should be made available for more people to benefit from the programme.
\end{abstract}

Key Word: Outreach, Performance, Micro finance, SPFS

\section{INTRODUCTION}

The underlying theory for the promotion of specialized institutions and programmes for agriculture is that, when loans are granted to farmers, they are empowered economically to have control over the other factors of production. At the farm level it is expected that when farmers are sufficiently provided with funding they stand the chance of increasing their production possibility frontier, income and asset holding. By implication, increase in food production by the recipient of loan will in turn boost total food supply at the national level. Therefore the overall objective of micro finance in this respect is the enhancement of the recipients' welfare through economic independence and the production of food in abundance.

For about a decade now, the term, micro finance has gained grounds world wide more than ever before. Among the people who are concerned with the planning and management of developing economies the concept has become a household word. In Nigeria, the concept has been popularized with the official launching of micro finance policy by the central bank of Nigeria (CBN, 2005).

According to the policy, micro finance is concerned with providing financial service to the poor who are traditionally not served by the conventional financial institution (CBN, 2005). Micro 
financial service differ from those of other financial institutions with respect to the smallness of loans advanced and /or saving collected, the absence of asset based collateral and the simplicity of operations (CBN, 2005). The reason for adopting this simple approach of rendering service is to achieve one of its objectives, which centers on reaching out to the majority of the poor who are economically active by the year, 2020.

Micro finance services are given through organizations or institutions, which could be formal or informal. Iganiga (2007) noted that formal organizations which participate in micro finance service delivery in Nigeria are; the universal Bank, Micro finance Banks, Non Governmental Organizations, Micro finance Institutions, Public Sector Poverty Alleviation Agencies, Specialized Micro finance Schemes and Donor Agencies. The informal or traditional micro finance organizations according to CBN (2005) are the Informal Self-Help Groups (SHGs), or Rotating Saving and Credit Associations (ROSCAs), Saving Collectors and Cooperative Societies. The traditional micro finance provider though more popular among the poor, have limited service coverage or outreach to economic active population. The major reason being that they operate with low capital base. The components of micro finance service are loans; cash deposit service, insurance and money transfer. Variation in the service provided depends on the objectives of any of the organizations.

This study is considered important given the fact that most economic active Nigerians who have need for micro finance service delivery cannot have the opportunity. Empirical evidence shows that less than $2 \%$ of rural household have access to financial services. For instance, the ratio of banks to rural inhabitants in Nigeria is 1:57,000 (CBN 2005). It is the recognition of the above problem that the Federal Government, Non-Governmental Organizations and Donor Agencies have over time established micro-finance base schemes to afford the poor people the opportunity to have access to micro finance services.

One of such micro finance based schemes in Abia State is the Special Programme on Food Security (SPFS). The broad objective of SPFS is to attain food security and the alleviation of rural poverty in Nigeria (ABIADEP, 2005). A major component of this programme is its micro finance service scheme. The micro finance component of the programme is meant to complement other services provided to farmers by the programme. The programme is to be implemented in phases. This study is designed to assess the first phase of the programme in the state.

Over the years financial analysts have adopted different criteria for assessing the performance of micro finance providers especially those who are involved in micro-enterprise financing. The earliest criteria used were rate of loan default and loan delinquency. These criteria are favoured on the argument that low delinquency rate implies that lenders are careful in selecting borrowers and in recovering loan. Vogel (1981), opined that, low rate of loan delinquency suggests that loans are allocated to productive activities. Another tool, which is used in assessing the performance of loan schemes, is financial ratios. They are more appropriate in assessing 
financial performance of profit maximizing organization but not suitable for schemes, which involve subsidies, that involve opportunity cost.

However, for micro finance schemes, which are targeted to the poor and micro-enterprise activities, Yaron et. al., (1997) introduced two criteria for assessment. These criteria are the levels of out-reach achieved among target clientele and the self-sustainability of the scheme. Self-sustainability criterion is used when subsidies are involved.

The broad objective of this study is to assess the performance of Special Programme on Food Security with respect to the outreach of its micro finance scheme. Specific objectives include the examination of what qualify beneficiaries to participate in the scheme, evaluate the extent the scheme has reached out to the target clientele and examine the factors that influence the demand for loan.

\section{METHODOLOGY}

The study was conducted in Abia State, Nigeria. The State is made up of 17 Local Government Areas and three Agricultural Zones. The Agricultural Zones are Aba, Umuahia and Ohafia. In the study area, are many microfinance providers of which the universal banks are the most popular. Other bank categories are Community Banks, and the Nigeria Agricultural Cooperative and Rural Development Bank (NACRDB). In the non-bank categories are Cooperative Societies, Informal Self Help Groups, Governmental and Non-Governmental Organization micro finance providers and programmes including the Special Programmme on Food Security (SPFS).

This study focuses on the outreach performance of SPFS in Abia state. This work covered the first phase of the programme in the state, which lasted for four years. The programme operates in three locations /Sites in the State. The sites, which are in Umuobasiukwu in Ohafia Agricultural Zone, Ihim in Umuahia Agricultural Zone and Obioza in Aba Agricultural Zone, were purposively selected for the study for equal coverage. From each of the three sites a list of loan beneficiaries was obtained with the help of the staff of SPFS. From these lists 20 beneficiaries of credit and 20 non-beneficiaries were selected from each of the programme sites using the random sampling technique. This gave a total of 120 respondents. Two sets of structured questionnaire were used to collect data from the programme staff and programme beneficiaries/non beneficiaries. In addition to using questionnaire for data collection, information relevant to the study was collected from publications and other written documents. Data on population of target clients were obtained from ADP (2005) and NPC (2006).

Data were analyzed with the use of simple statistical tools such as percentages, frequency distribution, and means. Equally applied to the data were the multiple regression analysis and the measures of outreach indicators. In this context, outreach refers to the proportion of the target population, which actually benefited from the micro finance service of the programme. Micro finance indicators are: number of beneficiaries and the percentage of beneficiaries who are 
women. Outreach of the target beneficiaries in each Agricultural Zone was obtained using the outreach indicators model.

The outreach model as used by Lafourcade, et al (2005) and Yaron et al (1997) is shown in equation (1).

$$
\text { Outreach level }=\underline{\text { Number of loan beneficiaries }} \times \underline{100}
$$

Target population in each zone

In order to ascertain the extent to which people in each Agricultural Zone are involved in SPFS programme, participation density is used. It is given as follows:

Participation Density $=\underline{\text { Beneficiaries in each Agricultural Zone }}$

Population in the Zone

The regression analysis was used to estimate the factors that affect household demand for micro credit of SPFS. The implicit functional form of the model is

$\mathrm{CD}=\mathrm{f}\left(\mathrm{X}_{1}, \mathrm{X}_{2}, \mathrm{X}_{3}, \mathrm{X}_{4}, \mathrm{X} 5, \mathrm{X} 6, \mathrm{X} 7, \mathrm{X} 8, \mathrm{X}_{9}\right)$

Where,

$\mathrm{CD}=$ Credit Demand (the amount of credit demanded in Naira)

$\mathrm{X}_{1}=$ Household income measured in Naira

$\mathrm{X}_{2}=$ Educational level (Number of years spent in school by household).

$\mathrm{X}_{3}=$ Skills in off-farm activities (with skill $=1$, without skill $=0$ )

$\mathrm{X}_{4}=$ The ratio of family labour to family population.

$\mathrm{X}_{5}=$ Household savings measured in Naira value

$\mathrm{X}_{6}=$ The ratio of off farm business income to income of household

$\mathrm{X}_{7}=$ Farm size measured in hectares

$\mathrm{X}_{8}=$ Loan transaction cost, the total cost for using the loan in Naira value.

$\mathrm{X}_{9}=$ Age of the farmer measured in years.

It is expected that household income, educational level of the household head, the ratio of family labour to family population, skills in off-farm activities, Household savings, Farm size will be positively related to the amount of credit demanded while Loan transaction cost and Age of the farmer will be inversely related to the amount of credit demanded

\section{Results and Discussion}

\section{Eligibility Criteria for Participation in SPFS Loan Programme.}

Prospective beneficiaries of the micro-credit programme of SPFS are required to meet specified lending conditions. These conditions, which centre on their socio-economic characteristics play important role in guiding the decision of the programme operators on whether or not to approve the loan.

The criteria used by SPFS in the selection of loan beneficiaries are as follows;

1 Beneficiaries must be farmers and should reside in the SPFS designated site. The programmes operations take place in three sites namely Ihim in Umuahia Agricultural Zone, Umuobasiukwu in Aba Zone and Obioza in Ohafia Zone. 
2 The beneficiaries must be able to adopt scientific packages extended by the programme. The reason is because the loan is meant to act as a complementary service to other activities of the programme.

3 A beneficiary must belong to at least one Cooperative Society. This is important because greater part of the SPFS loans is given through Cooperative Societies, under joint liability arrangement.

For a farmer to benefit in the programme the three conditions must be met. Tables 1 and 2 show the Respondents' status on the eligibility requirements.

\section{Adoption of Innovation by the Respondents}

Adoption of innovation of SPFS by Beneficiaries and non-beneficiaries is presented in Table 1. In this study we included non-loan beneficiaries as to capture the effect of the programme on the participants

Table 1: Distribution of the Respondents by Adoption of Innovations

\begin{tabular}{llclc}
\hline Status of adoption & Beneficiaries & \multicolumn{2}{l}{ Non Beneficiaries } \\
& Freq. & $\%$ & Freq. & $\%$ \\
\hline Adopted all innovations & 52 & 86.67 & 46 & 76.67 \\
$\begin{array}{l}\text { Do not adopt all } \\
\text { innovations }\end{array}$ & 8 & 13.33 & 14 & 23.33 \\
Total & 60 & & & \\
\hline
\end{tabular}

Source: Field Survey, 2007

Table1 shows that 86.67 percent of the beneficiaries and 76.67 percent of the non-beneficiaries adopted innovations packaged by Special Programme on Food Security. The result suggests that the ability of beneficiaries to adopt the innovations gave them a better chance to be selected than those who did not adopt the innovations. On the other hand, the programme enabled participants to adopt more innovations.

\section{Membership of Co-operative Societies}

Membership of Co-operative Societies by beneficiaries and non-beneficiaries is presented in Table 2

Table 2: Distribution of the Respondents according to Membership of Co-operative Society

\begin{tabular}{llrlr}
\hline Status of adoption & Beneficiaries & \multicolumn{2}{l}{ Non Beneficiaries } \\
& Freq. & \multicolumn{1}{l}{$\%$} & Freq & $\%$ \\
\hline Membership of Co-operatives & 60 & 100.00 & 29 & 48.33 \\
Not member of Co-operatives & 0 & 0.00 & 31 & 51.67 \\
Total & 60 & 100.00 & 60 & 100.00 \\
\hline
\end{tabular}

Source: Field Survey, 2007

Table 2 shows that all the beneficiaries of the micro-credit scheme of SPFS belong to Cooperative Societies. Their membership of Cooperatives gave them advantage over their counterparts who are not members of Co-operative Societies. For non-beneficiaries of the loan, 
48 percent belong to Cooperative Societies. These people could not qualify for the loan probably either because their Co-operative Societies did not meet the requirement for SPFS loans, or they did not adopt the recommended innovations.

\section{Determinants of SPFS credit demand}

Factors that influence the demand for SPFS loans are presented in Table 3

Table 3 Regression Results on Household Demand for SPFS Micro credit

\begin{tabular}{|c|c|c|c|c|}
\hline $\begin{array}{l}\text { Explanatory } \\
\text { Variable }\end{array}$ & Linear function & Exponential function & Semi $\log +$ & Double log \\
\hline Constant & $\begin{array}{l}-102623.7 \\
(0.1109)\end{array}$ & $\begin{array}{l}9.171 \\
(9.961) * * *\end{array}$ & $\begin{array}{l}-364328.2 \\
(-0.774)\end{array}$ & $\begin{array}{l}9.578 \\
(1.972)^{* *}\end{array}$ \\
\hline $\mathrm{X}_{1}$ & $\begin{array}{l}0.251 \\
(0.2519) * * *\end{array}$ & $\begin{array}{l}1.80 \mathrm{E}-006 \\
(1.554)^{*}\end{array}$ & $\begin{array}{l}9707.161 \\
(0.377)\end{array}$ & $\begin{array}{l}-0.088 \\
(-0.331)\end{array}$ \\
\hline $\mathrm{X}_{2}$ & $\begin{array}{l}6513.482 \\
(1.760)^{*}\end{array}$ & $\begin{array}{l}0.101 \\
(2.732) * * *\end{array}$ & $\begin{array}{l}51034.180 \\
(1.786)^{*}\end{array}$ & $\begin{array}{l}0.689 \\
(2.338)^{* *}\end{array}$ \\
\hline$X_{3}$ & $\begin{array}{l}-30.658 \\
(-0.742)\end{array}$ & $\begin{array}{l}-0.001 \\
(-1.515)^{*}\end{array}$ & $\begin{array}{l}-5472.634 \\
(-1.132)\end{array}$ & $\begin{array}{l}-0.058 \\
(-1.707)\end{array}$ \\
\hline $\mathrm{X}_{4}$ & $\begin{array}{l}378110.041 \\
(1.258)\end{array}$ & $\begin{array}{l}0.373 \\
(1.247)\end{array}$ & $\begin{array}{l}77399.849 \\
(2.293)^{* *}\end{array}$ & $\begin{array}{l}0.707 \\
(2.031)^{* *}\end{array}$ \\
\hline $\mathrm{X}_{5}$ & $\begin{array}{l}-1.056 \\
(-0.044)\end{array}$ & $\begin{array}{l}0.000 \\
(0.734)\end{array}$ & $\begin{array}{l}-2752.061 \\
(-0.453)\end{array}$ & $\begin{array}{l}-0.082 \\
(-1.301)\end{array}$ \\
\hline $\mathrm{X}_{6}$ & $\begin{array}{l}-3191.812 \\
(-0.221)\end{array}$ & $\begin{array}{l}-0.084 \\
(-0.587)\end{array}$ & $\begin{array}{l}4852.355 \\
(2.322) * *\end{array}$ & $\begin{array}{l}0.526 \\
(2.441)^{* * * *}\end{array}$ \\
\hline $\mathrm{X}_{7}$ & $\begin{array}{l}-1.429 \\
(-0.808)\end{array}$ & $\begin{array}{l}-1.30 \mathrm{E}-005 \\
(-0.740)\end{array}$ & $\begin{array}{l}1850.749 \\
(0.226)\end{array}$ & $\begin{array}{l}0.004 \\
(0.048)\end{array}$ \\
\hline $\mathrm{X}_{8}$ & $\begin{array}{l}2092.978 \\
(1.280)\end{array}$ & $\begin{array}{l}0.020 \\
(1.237)\end{array}$ & $\begin{array}{l}62306.578 \\
(0.814)\end{array}$ & $\begin{array}{l}0.355 \\
(0.449)\end{array}$ \\
\hline $\mathrm{X}_{9}$ & $\begin{array}{l}23.311 \\
(0.475)\end{array}$ & $\begin{array}{l}0.000 \\
(0.441)\end{array}$ & $\begin{array}{l}-928.083 \\
(-1.771)^{* *}\end{array}$ & $\begin{array}{l}0.029 \\
(0.118)\end{array}$ \\
\hline $\mathrm{R}$ & 0.586 & 0.671 & 0.728 & 0.715 \\
\hline $\mathrm{R}^{2}$ & 0.343 & 0.381 & 0.529 & 0.511 \\
\hline F-ratio & $2.029 * *$ & $2.394 * *$ & $3.250 * * *$ & $3.021 * * *$ \\
\hline
\end{tabular}

Source: Field Survey, 2007. Figure in parenthesis are t-ratio, + lead Equation,

*significant at 10.0 percent, **significant at 5.0 percent, ***significant at 1.0 percent.

The semi-log functional form of the regression analysis was chosen as the lead equation. The reason is because; the value of the Coefficient of Multiple determination $\left(\mathrm{R}^{2}\right)$, which is 0.529 or $53 \%$, is statistically significant and reasonably high. 
In addition, the F -ratio is statistically significant at one (1) percent alpha level and the results obtained from most of the explanatory variables in the model agree with theoretical and economic expectations.

The result in Table 3 shows that four variables are significant in influencing household demand for SPFS credit demand. These variables are level of education, skill in off-farm activities, farm size and loan transaction cost.

The level of education of household head had positive correlation with the amount of loan demanded and it was statistically significant. This result suggests that the respondents who acquired more formal education demanded more loan than those who acquired less formal education. This finding appears to be in agreement with theoretical expectation because people who acquire more education have a better chance of managing bigger commercial ventures than those who acquire less. This is so because; better managerial skill is acquired through formal training.

Skill in off farm activity was positively correlated with the amount of loan demanded. The result indicated that respondents who have skills in off farm activities demand more loan than their counterparts who engage only in agricultural activities. Intuitively, this finding makes sense because; acquisition of skill outside agricultural related enterprises offers the same advantage as those of formal education. Some of the respondents have skills, which qualify them to belong to specialize Co-operative Societies, which helped them to meet the conditions for benefiting from SPFS loan.

The relationship between the farm size and the amount of loan demanded by the respondents was positive and significant. The implication is that, respondents who manage larger farm size demanded more loans than those whose farm size are smaller. The reason is because larger farms require more inputs to manage. The acquisition of such inputs like labour, seedlings, chemical and farm equipment could only be possible when there is money. The need for more money acts as a motivation to owners of large farms to source for more money.

The influence of loan transaction cost on the amount of money demanded was significant and negative. This result agrees with theoretical expectation because, transaction cost represents the price of acquiring the loan. Following from the primary theory of demand, the quantity of a commodity or service demanded varies inversely with the price of that commodity or service within a given time.

\section{Performance of SPFS Based on Outreach Achievement}

The level of outreach achieved by the programme is measure used to assess the percentage of the target clients covered by the programme with credit facilities. In Table 4 the percentage of the target clients serviced with credit facilities in each of the three location sites are shown. 
Table 4: Outreach level achieved by SPFS in the various Sites in the State

\begin{tabular}{lllll}
\hline Outreach Indicators & Ihim & Ummuosiukwu & Obioza & State
\end{tabular}

\begin{tabular}{lrlcc}
\hline Number beneficiaries & 295 & 290 & 290 & 875 \\
Number of women reached & 89 & 87 & 87 & 263 \\
Population of target clients & 570350.3 & 60851.22 & 517340.24 & 1696271.8 \\
Outreach level (\%) & 0.052 & 0.048 & 0.056 & 0.052 \\
\hline
\end{tabular}

Source: Field Survey, 2007

Table 4 shows that the level of outreach achieved (that is the number of target clients served) in the three programme locations differed a little. The marginal difference in the number of clients served in each programme location is an indication that the credit service of the programme is evenly spread across the State. However, the overall outreach of $0.052 \%$ could be said to be low relative to the population of the target population. This confirms the finding of Mejeha and Echibiri (2006) which observed that the total financial services outreach in Abia State was less than one (1) percent. The Authors considered the outreach level of less than one (1) to be too low when compared with of similar organizations in many developing countries, like India and Bangladesh with outreach performance of 20 and 15 percent respectively

The problems which were associated with low outreach performance of the programme are; inadequate funds and late release of funds, low loan recovery rate, inadequate facilities for effective monitoring, high cost of farm inputs and lack of awareness of the most target client.

\section{Outreach Coverage by Gender}

Table 5 shows the percentage of woman who benefited from NSPFS loan in each of the three programme locations

Table 5: Frequency Distribution of Loan Beneficiaries by Gender

\begin{tabular}{|c|c|c|c|c|c|c|c|c|}
\hline & Ihim & & Umuobasiukwu & & Obioza & & State & \\
\hline Gender & No. & $\%$ & No. & $\%$ & No & $\%$ & No & $\%$ \\
\hline Male & 206 & 69.83 & 203 & 70 & 203 & 70 & 612 & 69.95 \\
\hline Female & 89 & 30.17 & 87 & 30 & 87 & 30 & 263 & 30.06 \\
\hline Total & 295 & 100.00 & 290 & 100.00 & 290 & 100 & 875 & 100.00 \\
\hline
\end{tabular}

Source: Field Survey, 2007

Table 5 shows that the distribution of the beneficiaries in the three programme sites is almost uniform. This is perhaps an effort to ensure equitable and fair distribution of the beneficiaries across the state. There is however a wide disparity between the number of male beneficiaries and female loan beneficiaries. The reason could be explained by the fact that beneficiaries were selected based on their ability to meet the eligibility criteria for granting loans. This finding lends 
supports to the view that women are economically disadvantaged and as a result find it difficult to access institutional loans (Damisa et al.,2007).

Remarkably, the programme operators seem to be gender sensitive in the allocation of loans. This is so because in all the three programme sites, the percentage of women who benefited from loan was about 30 percent. The percentage of their male counterpart was about 70 percent. This is perhaps a conscious effort to follow the current trend world wide in handling issues that border on gender empowerment.

\section{Participation Density of SPFS Micro-Credit in Abia State}

Participation Density is another measure of outreach. It is used to estimate the extent to which people in each Agricultural Zone are involved in the SPSF micro-credit programme. It is used to ascertain the number of micro-credit beneficiaries from every 10000 people in each Agricultural Zone. Table 6 shows the participation density in each of the three Agricultural Zones.

Table 6: Participation Densities in Micro-Credit of SPFS Micro-Credit in Abia State

\begin{tabular}{lllll}
\hline Indicator & Ihim & Umuobasiukwu & Obioza & State \\
& & & & \\
\hline Beneficiaries in each Agricultural Zones & 295 & 290 & 290 & 875 \\
Agricultural Zones Population & 885831 & 785719 & 1162449 & 2833999 \\
\hline Participation Density & 0.00033 & 0.00037 & 0.00025 & 0.00031 \\
\hline
\end{tabular}

Source: Field Survey, 2007

Table 6 shows that the participation density in the state was 0.00031 . This suggests that in every 10000 people three (3) persons benefited from the micro-credit. The higher the value of participation density the more is the outreach achievement. The participation density in Obioza is least. For higher participation density to be achieved, more people in should be given credit facility.

\section{Conclusion}

Special Programme for Food Security has gained ground in Abia State, Nigeria. By operating in the three zones of the state, the programme has the potential of reaching out to the majority of the target client. The modalities adopted by the programme in credit allocation are fairly balanced in view of the fact that the number of loan beneficiaries in each of the three agricultural zones varied a little. In addition, the percentage of women beneficiaries was uniform in the three location sites. The outreach coverage of 0.052 percent achieved by the first of its operation is very low relative to the target population. In view of the above findings, we recommend that the financiers of the programme should increase the amount of fund for the next phase of the programme. For a better outreach to be achieved target population should be encouraged through awareness creation to join cooperative societies and adopt the technologies recommended to farmers by the programme. 


\section{REFERENCE}

Abia State Agricultural Development Programme (2005). Implication Completion Report (ICR) first phase.

Central Bank of Nigeria (2005). Microfinance Policy, Regulatory and Supervisory Framework for Nigeria, Central Bank of Nigeria of Abuja.

Damisa, M.A;R. Samndi and M. Yohanna (2007). Women Participation in Agricultural Production: A Profit Analysis. Journal of Applied Sciences, 7 (3): 412-416.

Iganiga, B. O. (2007). An Evaluation Microfinance Policies and Institution in Nigeria. Union Digest. An Economic and Business Publication of Union Bank of Nigeria Plc. Vol. 11, No. 1 and 2, pp. 60-74.

Kefas, S. D. (2005). Fighting Poverty through Empowering Women with Microfinance. Nigerian Quarterly Microfinance Newsletter, vol. 2, pp. 3-4.

Lafourcade, A., J. Isem, P. Mwangi and M. Brown (2005). Overview of the Outreach and Financial Performance of Microfinance Institutions in African. www.cgap.org and www.mixmarket.org.

Mejeha, R. O. and G. E. Ifenkwe (2007). Density and Microfinance Service Coverage of Rural Banks in Nigeria. International Journal of Agriculture and rural Development (IJARD), vol. 10, No. 2, pp. 1-6.

Mejeha, R. O., R. N. Echebiri (2006). Outreach of Financial Service Delivery by Rural Bank Branches serving Agricultural and Rural Sectors of Abia state, Nigeria: Policy implication. Journal of Agriculture and Food Science, vol. 4, No. 1, pp.67-76.

National Population Commission (2006). Federal Government of Nigeria-official gazette No.24, Vol.9.

Vogel, R. C. (1981). Rural Financial Market Performance: Implications of Low Delinquency Rates. American Journal of Agricultural Economics, vol. 63, No. 1, pp. 58-72.

Yaron, J., M. P. Benjamin and S. L. Piprik (1997). Rural finance Issues, Design and Best Practices. The World Bank Washington D. C. 